\title{
Nutritional assessment of charitable meal programmes serving homeless people in Toronto
}

\author{
Carmen Tse and Valerie Tarasuk* \\ Department of Nutritional Sciences, Faculty of Medicine, University of Toronto, Toronto, ON, Canada M5S 3E2
}

Submitted 17 August 2007: Accepted 16 April 2008: First published online 12 June 2008

\begin{abstract}
Objectives: To assess the potential nutritional contribution of meals provided in a sample of community programmes for homeless individuals, to determine the effect of food donations on meal quality and to develop food-based guidance for meals that would meet adults' total nutrient needs.

Setting: Toronto, Canada.

Design: An analysis of weighed meal records from eighteen programmes. The energy and nutrient contents of meals were compared to requirement estimates to assess contribution to total needs, given that homeless people have limited access to nutritious foods. Mixed linear modelling was applied to determine the relationship between the use of food donations and meal quality. The composition of meals that would meet adults' nutrient requirements was determined by constructing simulated meals, drawing on the selection of foods available to programmes.

Sample: In all, seventy meals, sampled from eighteen programmes serving homeless individuals.

Results: On average, the meals contained 2.6 servings of grain products, 1.7 servings of meat and alternatives, $4 \cdot 1$ servings of vegetables and fruits and $0 \cdot 4$ servings of milk products. The energy and nutrient contents of most meals were below adults' average daily requirements. Most meals included both purchased and donated foods; the vitamin $\mathrm{C}$ content of meals was positively associated with the percentage of energy from donations. Increasing portion sizes improved the nutrient contribution of meals, but the provision of more milk products and fruits and vegetables was required to meet adults' nutrient requirements.

Conclusions: The meals assessed were inadequate to meet adults' nutrient requirements. Improving the nutritional quality of meals requires additional resources.
\end{abstract}

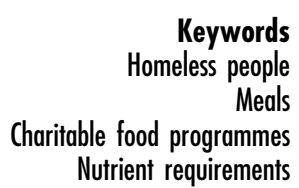

As the number of people who are homeless (i.e. living in public spaces or temporary accommodation because they lack safe, secure housing) swells ${ }^{(1-3)}$, communities across Canada are struggling to establish and sustain effective responses. Vulnerability to poorer physical $^{(4-6)}$ and mental health ${ }^{(7-10)}$, poorer self-rated health ${ }^{(11)}$ and higher rates of mortality ${ }^{(8,12-14)}$ are well-documented among homeless individuals in Canada. Furthermore, a growing body of research suggests that the food and nutrition needs of many homeless people are poorly met ${ }^{(15-20)}$. Given the inadequacy of income assistance programmes, lack of affordable housing and increasingly restrictive eligibility criteria for existing supports and services, much of the assistance available to homeless people comes from community-based initiatives to help them meet basic subsistence needs for shelter, food, personal hygiene and primary health care. Local food provisioning efforts typically include soup kitchens, street outreach programmes and meal provisions in shelters, but meals and snacks are also now being offered on a smaller scale by an increasing number of social service agencies, drop-in centres and health centres ${ }^{(11)}$. The programmes are largely ad hoc, voluntary initiatives, with the scope of operations varying from two to three meals per day most days of the week to a single meal per week. Many programmes rely on donated foodstuffs from food banks ${ }^{(21)}$ and other charitable food redistribution networks, though both the quantity and nutritional quality of foods garnered through this route are limited ${ }^{(22-28)}$. Concerns about the appropriateness and effectiveness of these efforts stem from the high levels of food deprivation documented among samples of homeless individuals ${ }^{(15,17-20)}$, and also a recent study in Toronto that found homeless youth who used charitable meal programmes to be as nutritionally vulnerable as those who did not ${ }^{(11,20)}$.

Concerns about the adequacy of nutrition supports for homeless groups are not unique to Canada. Studies in 
Europe ${ }^{(29-31)}$, Australia ${ }^{(32,33)}$ and the United States ${ }^{(34-39)}$ have also raised questions about the capacity of community food programmes to meet the food needs of homeless people. Assessments of the meals provided in soup kitchens in the USA have shown them to be of poor nutritional quality and particularly limited in fruits and vegetables $^{(36,37,40)}$. An assessment of the dietary intakes of men using a shelter in Paris has also documented nutritional deficits linked to the suboptimal quality of shelter meals ${ }^{(30)}$. As an initial step towards understanding the meal provisioning efforts of community programmes in Canada, the present study examines the nutritional contribution of a sample of meals offered in eighteen programmes serving homeless individuals in Toronto, investigates the effect of food donations on the nutrient contents of meals provided and develops food-based guidelines for the construction of meals to meet adults' estimated average nutrient requirements.

\section{Sample and methods}

In August 2004, an inventory of programmes serving meals to homeless adults in Toronto was conducted, drawing on data from a web-based community resource ('211 Toronto'), as well as data on the meal/snack programmes receiving food from the three major charitable food assistance distributors in this area and programmes participating in a winter relief programme. A brief telephone survey designed to obtain information on programme characteristics was completed with workers in 148 of the 157 programmes identified (94\%) (results to be reported elsewhere). From the survey sample, eighteen programmes were selected for in-depth study, applying purposive sampling to capture programmes with different histories (considering time since inception and reasons for beginning meal service), styles of service delivery (e.g. meals offered in isolation or in conjunction with other services) and geographic locations within the city. We conducted participant observations and an open-ended interview with the coordinator in each programme (results to be reported elsewhere). In addition, over a 6-8-week period from September 2004 to April 2005, a single meal was weighed and measured on four separate occasions in sixteen programmes. Because of scheduling problems, meals were recorded on only three occasions in two programmes. In nine programmes that regularly served more than one meal, the meal of highest attendance was recorded. The meals recorded represented 'best-case scenarios', assuming ample quantities of all meal items were available for all, throughout the meal period. The origin of each meal item was also recorded, differentiating between foods that had been purchased by programmes and those that had been obtained free of charge. The latter category included foods supplied by the local food bank and a 'surplus' food redistribution network operating in Toronto, as well as food donations solicited by programme staff from food retail or food service outlets.

The weighed meal records were entered into the Nutrition Survey System (NSS) software (a food composition database based on the 1997 Canadian Nutrient File) to estimate the energy and nutrient content of each meal. The US Department of Agriculture Food Composition Tables were used to obtain vitamin A values for foods in retinol activity equivalents (RAE) to facilitate comparison with requirements ${ }^{(41)}$. All analyses were conducted using SAS/PC Version $9 \cdot 1^{(42)}$.

\section{Evaluation of meals}

For each meal recorded, the number of servings from each food group defined in Canada's Food Guide $(\mathrm{CFG})^{(43)}$ (i.e. grain products, fruits and vegetables, meat and alternatives, and milk and alternatives) was calculated. The energy and nutrient contents of meals were compared to adults' average daily requirements to assess the meals' contribution towards the total needs of clients. While this might seem like an unrealistically high standard for single meals, studies of the dietary patterns and food acquisition strategies of homeless individuals in Canada suggest that it cannot be assumed that a substantial amount of nutrients come from other sources ${ }^{(15,17,20,44)}$. To assess nutrient contribution, the mean protein, vitamin $\mathrm{A}$, vitamin $\mathrm{C}$, folate, vitamin $\mathrm{B}_{6}$, riboflavin, thiamin, niacin, iron, phosphorus, magnesium and zinc contents of the three or four meals recorded in each programme were compared to the estimated average requirements (EAR) for these nutrients ${ }^{(45-49)}$. The EAR represent the median requirements of different age-sex groups, and they can be understood as unbiased estimates of nutritional needs for any randomly selected person within the population ${ }^{(49)}$. The requirement estimates for males and females, 31-50 years old, were used in the analysis because they comprise the single largest age grouping of homeless adults in Toronto ${ }^{(3)}$, and the requirement estimates of 31-50-year-olds equal or exceed those for younger or older adults for most nutrients ${ }^{(45-49)}$. To permit comparison of the protein content of meals with protein requirements expressed as grams/kilograms of body weight/day, the body weights of people consuming the meals were approximated as the weights of the population 'reference' male and female ${ }^{(49,50)}$. Total fibre and calcium were assessed by comparing programme means to the Adequate Intake levels (AI) for these nutrients ${ }^{(49)}$. To assess the energy contribution of meals, the mean energy content of meals sampled in each programme was compared to the estimated energy requirements (EER) of the reference adult male and female, 31 years of age ${ }^{(50)}$. The smallest BMI in the healthy range $\left(18.5 \mathrm{~kg} / \mathrm{m}^{2}\right)$ was chosen for comparison to determine whether the lowest energy needs of a reference individual could be met by the average meals of 
programmes, but the calculations were repeated assuming different levels of physical activity levels to generate the range of requirements for a person this size.

In nine programmes where more than one option was offered in a meal (e.g. a choice of two kinds of sandwiches), only the option with the greatest energy content was included in comparisons with requirement estimates; an analysis of other options indicated that they had lower nutritional contributions.

\section{Development of food-based meal guidelines to meet participants' nutrient needs}

Two modelling exercises were undertaken to determine the changes required for programmes to provide meals that met individuals' total nutrient needs, and thus develop food-based guidance for programme operators. Total need was represented by the EAR and AI for 31-50-year-olds because meals containing this level of nutrition could be assumed to meet the average nutrient requirements of programme participants. It was important that a single meal satisfy an individual's daily nutrient requirements because of homeless people's limited access to nutrients from other sources ${ }^{(15,17,20,44)}$. Individuals could consume more than one meal per day in a programme and thus not require a single meal to fulfil their nutrient needs, but this would likely only pertain to shelter users. Half of the programmes studied served only one meal per day (Table 1), and those serving more meals reported much lower attendance at other meals (in some cases because features of the meal service functioned to restrict attendance), suggesting that the nutritional benefit of the additional meals would be experienced only by a small proportion of clients. Individuals could conceivably eat at more than one programme each day, but distances between programmes and lack of coordination in meal schedules would make it difficult to accomplish this on a daily basis.

To determine whether simply increasing the amounts of food provided would be sufficient for the meals to meet the total needs, portion sizes of foods in the originally recorded meals in all programmes except one were increased proportionally to their energy content so that the average energy content of the meals of each programme was equal to the EER of a small, sedentary reference female, 31 years of age $(7574 \mathrm{~kJ} / 1809 \mathrm{kcal})^{(50)}$. This EER can be considered the lower bound of energy requirements for clients (assuming most individuals would be larger and more physically active), and it also can represent a viable (albeit high) energy content for a single meal. In fact, the mean energy content of meals in one programme exceeded this level, so it was proportionately reduced to obtain a mean of $7574 \mathrm{~kJ} /$ $1809 \mathrm{kcal}$. The nutrient contents of adjusted meals were calculated and compared to the EAR and AI.

The selection and amount of foods required for meals to meet adults' total nutrient requirements were determined by an iterative process to construct meals de novo, assuming no changes in the selection of foods available to programmes but ample quantities of all foods. All foods recorded in the observed meals were grouped into the food groups defined in $\mathrm{CFG}^{(43)}$, with fruits and vegetables further subdivided into vitamin C-rich, vitamin A-rich, folate-rich and 'other' fruits and vegetables in order to specifically target these three nutrients. Beginning with a meal that consisted of two servings from each of the seven food categories, the minimum number of servings required from each food category was determined through a process of systematically adding or subtracting single servings from various categories. With each change, test meals were assembled from randomly selected food items within each category, and the mean nutrient contents of thirty randomly assembled test meals were compared to the EAR of men, 31-50 years old, and women's EAR for iron (i.e. the only nutrient for which women's requirements exceed men's).

\section{Effect of food donations}

Food donations were used by fourteen of the eighteen programmes, although most meals in these programmes included both purchased and donated foods. Given the widespread concern about the quality of food available for distribution through food banks in Canada ${ }^{(22-28)}$, we hypothesised that depending on food donations would pose a constraint on meal quality in these programmes. Representing the contribution of food donations by the percentage of energy from donated foods in a meal, mixed linear modelling was conducted to determine the effect of food donations on the energy and nutrient content of meals and the number of servings from each food group. Because the use of maximum likelihood estimation methods in mixed linear modelling assumes that the dependent variable is normal, the distributions of all variables were reviewed. Box-Cox transformations were applied to energy and all nutrient variables to ensure that they approximated normal distributions ${ }^{(51)}$, and mixed linear models were run using the Residual Maximum Likelihood estimation method (REML). Although the servings of vegetables and fruits in meals appeared normal without transformation, the distributions of servings from the other food groups were skewed and could not be transformed to approximate normality. The mixed linear models for all food groups were run using Minimum Variance Quadratic Unbiased Estimation (MIVQUE0), a method that, while less powerful than REML ${ }^{(42)}$, can be used with non-normal data. This method was applied for servings of vegetables and fruits for consistency.

\section{Results}

The eighteen meal programmes included in the present study varied widely in terms of size and scope (Table 1). Only the three shelter programmes served three meals 
Table 1 Descriptions of programmes

\begin{tabular}{|c|c|c|c|c|}
\hline \multirow[b]{2}{*}{ Programme } & \multirow[b]{2}{*}{ Description of service } & \multirow[b]{2}{*}{ Meal recorded } & \multicolumn{2}{|c|}{ Clients served } \\
\hline & & & $n$ & $\%$ Regulars \\
\hline A & $\begin{array}{l}\text { Health centre provides a self-serve lunch in a meal room on } \\
\text { the weekdays during the wintertime }\end{array}$ & Lunch & 80 & 50 \\
\hline B & $\begin{array}{l}\text { Winter meal programme serves two rounds of both breakfast } \\
\text { and lunch, a dinner and a snack on Sundays. This } \\
\text { programme is part of a larger organisation that provides } \\
\text { other services }\end{array}$ & Lunch & $150-300$ & 65 \\
\hline C & $\begin{array}{l}\text { A purpose-built shelter programme caters to youth; every day } \\
\text { it serves three meals, a snack and a meal-to-go for users } \\
\text { who request it }\end{array}$ & Dinner & $60-80$ & 100 \\
\hline $\mathrm{D}$ & $\begin{array}{l}\text { A meal programme offers breakfast and lunch on the } \\
\text { weekdays. Other services are available within the larger } \\
\text { organisation }\end{array}$ & Lunch & $50-150$ & 90 \\
\hline$E$ & $\begin{array}{l}\text { The free meal of a programme serves brunch on the } \\
\text { weekdays and dinner on weekdays plus Saturdays. The } \\
\text { food programme is part of a larger organisation that } \\
\text { provides a variety of services, including housing }\end{array}$ & Dinner & 30 & 95 \\
\hline G & $\begin{array}{l}\text { A mobile meal service offers breakfast to those living outdoors } \\
\text { on Wednesday to Saturday }\end{array}$ & Breakfast & 85 & 75 \\
\hline $\mathrm{H}$ & $\begin{array}{l}\text { A meal programme that offers Wednesday dinners, Thursday } \\
\text { breakfasts and Sunday brunches }\end{array}$ & Dinner & 225 & 80 \\
\hline I & $\begin{array}{l}\text { A meal programme caters to ex-psychiatric clients, serving } \\
\text { breakfast and lunch on the weekdays and only lunch on } \\
\text { Saturdays }\end{array}$ & Lunch & $140-185$ & $80-100$ \\
\hline J & $\begin{array}{l}\text { A drop-in programme offers breakfasts on Monday and } \\
\text { Saturday (winter only) and dinners on Wednesday nights }\end{array}$ & Dinner & $65-85$ & $90-92$ \\
\hline K & $\begin{array}{l}\text { Ad hoc shelter programme receives three catered meals and } \\
\text { a snack every day }\end{array}$ & Dinner & 70 & 100 \\
\hline L & $\begin{array}{l}\text { A drop-in programme offers a small snack and lunch every } \\
\text { weekday }\end{array}$ & Lunch & 45 & 90 \\
\hline M & $\begin{array}{l}\text { A multi-service programme offers shelter; every day it serves } \\
\text { a morning snack, two rounds of lunch, a take-away lunch } \\
\text { and dinner }\end{array}$ & Lunch & $50-300$ & 75 \\
\hline $\mathrm{N}$ & $\begin{array}{l}\text { A health clinic provides a self-serve lunch every weekday for } \\
\text { clients }\end{array}$ & Lunch & 30 & 30 \\
\hline $\mathrm{O}$ & $\begin{array}{l}\text { A drop-in programme for women serves breakfast and lunch } \\
\text { every day of the week }\end{array}$ & Lunch & $50-90$ & 80 \\
\hline$P$ & $\begin{array}{l}\text { Youth arts initiative serves a participant-prepared lunch on } \\
\text { Tuesdays and Thursdays }\end{array}$ & Lunch & 30 & 80 \\
\hline Q & $\begin{array}{l}\text { A meal programme started by educators serve dinners on } \\
\text { Fridays and breakfasts on Saturdays and Sundays }\end{array}$ & Breakfast & $60-80$ & $30-40$ \\
\hline $\mathrm{R}$ & $\begin{array}{l}\text { A purpose-built shelter programme caters to youth; every day } \\
\text { it serves three meals, a snack and a meal-to-go for users } \\
\text { who request it }\end{array}$ & Dinner & 52 & 100 \\
\hline$S$ & A meal programme serves dinner on Tuesday nights & Dinner & 65 & 85 \\
\hline
\end{tabular}

daily on all seven days of the week. The proportion of clients who ate regularly at the programmes ranged from $30 \%$ to $100 \%$.

The mean energy content of meals ranged from $2721 \mathrm{~kJ}$ $(650 \mathrm{kcal})$ in a dinner programme operating $6 \mathrm{~d} /$ week to $8750 \mathrm{~kJ}(2090 \mathrm{kcal})$ in a dinner programme operating once weekly (Table 2). The meals in most programmes would provide less than two-thirds of the EER of a small, sedentary reference male or female $(9261 \mathrm{~kJ}$ (2212 kcal) and $7574 \mathrm{~kJ}$ ( $1809 \mathrm{kcal})$, respectively) and less than half of the EER if high levels of physical activity were assumed $(12971 \mathrm{~kJ}(3098 \mathrm{kcal})$ and $10718 \mathrm{~kJ}(2560 \mathrm{kcal})$ for males and females, respectively).

The meals in most programmes included $\geq 1$ servings of grain products, meat and alternatives, and vegetables and fruit, but $\leq 0 \cdot 25$ servings of milk products (Table 2 ). Seven programmes provided meals that, on average, contained the recommended number of daily meat and meat alternatives servings for women in CFG, and one programme provided sufficient fruits and vegetables to meet the daily recommendation for women. For the most part, however, the average number of servings for each of the four food groups fell well below the daily recommendations for both men and women.

Wide variability was found in the nutrient content of the meals (Table 3). Both the mean and median levels fell below EAR for vitamin A, folate, magnesium and zinc, but the mean levels of other nutrients examined approximated or exceeded the EAR (Table 3). When the meals were examined by programme, the only nutrient provided in levels at or above the average requirements in almost all programmes was niacin. More than half the programmes had mean riboflavin, folate, zinc and vitamins $\mathrm{A}, \mathrm{B}_{6}$ and $\mathrm{C}$ contents below EAR for both men and women, and all 
Table 2 Mean energy content and number of food servings in the meals of each programmes and the recommended number of servings from Canada's Food Guide*

\begin{tabular}{|c|c|c|c|c|c|c|c|c|c|c|c|c|}
\hline \multirow[b]{3}{*}{ Programme } & & & \multirow{2}{*}{\multicolumn{2}{|c|}{ Energy (kcal) }} & \multicolumn{8}{|c|}{ Number of servings } \\
\hline & \multicolumn{2}{|c|}{ Energy (kJ) } & & & \multicolumn{2}{|c|}{ Meat and alternatives } & \multicolumn{2}{|c|}{ Grain products } & \multicolumn{2}{|c|}{ Milk and alternatives } & \multicolumn{2}{|c|}{ Vegetable and fruits } \\
\hline & Mean & SD & Mean & SD & Mean & $\mathrm{SD}$ & Mean & SD & Mean & SD & Mean & SD \\
\hline A & 4815 & 1172 & 1150 & 280 & $1 \cdot 0$ & 0.6 & $3 \cdot 1$ & 1.9 & $1 \cdot 4$ & $1 \cdot 0$ & $4 \cdot 2$ & 2.9 \\
\hline B & 3601 & 963 & 860 & 230 & $1 \cdot 3$ & 0.9 & 1.5 & $1 \cdot 8$ & 0.2 & 0.2 & $4 \cdot 3$ & $1 \cdot 0$ \\
\hline C & 4982 & 1465 & 1190 & 350 & $2 \cdot 3$ & $1 \cdot 4$ & $1 \cdot 7$ & $2 \cdot 2$ & 0.3 & 0.5 & $7 \cdot 2$ & $3 \cdot 1$ \\
\hline D & 3517 & 502 & 840 & 120 & $1 \cdot 6$ & 0.7 & $1 \cdot 4$ & $1 \cdot 0$ & 0.2 & 0.4 & $5 \cdot 7$ & $1 \cdot 3$ \\
\hline E & 2721 & 670 & 650 & 160 & 0.2 & 0.2 & $3 \cdot 2$ & $2 \cdot 2$ & $0+$ & & $2 \cdot 3$ & $1 \cdot 3$ \\
\hline G & 4731 & 628 & 1130 & 150 & $0 \cdot 7$ & 0.6 & $4 \cdot 8$ & $2 \cdot 1$ & 0.6 & 0.3 & $1 \cdot 0$ & $1 \cdot 0$ \\
\hline $\mathrm{H}$ & 6992 & 2302 & 1670 & 550 & $2 \cdot 4$ & $2 \cdot 0$ & $2 \cdot 0$ & 0.7 & $1 \cdot 7$ & $1 \cdot 1$ & $5 \cdot 7$ & $2 \cdot 2$ \\
\hline I & 5066 & 1214 & 1210 & 290 & 1.9 & $2 \cdot 1$ & $5 \cdot 3$ & $4 \cdot 4$ & 0.1 & 0.1 & $3 \cdot 0$ & $1 \cdot 4$ \\
\hline $\mathrm{J}$ & 5485 & 1172 & 1310 & 280 & $2 \cdot 1$ & $1 \cdot 6$ & $4 \cdot 3$ & $2 \cdot 3$ & 0.2 & 0.2 & $2 \cdot 3$ & 0.4 \\
\hline K & 4773 & 921 & 1140 & 220 & $2 \cdot 4$ & 0.7 & $2 \cdot 3$ & $2 \cdot 5$ & $0 \cdot 1$ & 0.2 & $2 \cdot 7$ & $2 \cdot 3$ \\
\hline L & 3224 & 921 & 770 & 220 & $1 \cdot 1$ & $1 \cdot 1$ & $1 \cdot 2$ & $1 \cdot 4$ & $0 \cdot 1$ & $0 \cdot 1$ & $2 \cdot 5$ & $1 \cdot 1$ \\
\hline $\mathrm{M}$ & 4647 & 963 & 1110 & 230 & $1 \cdot 6$ & 0.4 & 0.9 & $1 \cdot 5$ & 0.2 & $0 \cdot 1$ & $3 \cdot 2$ & 0.4 \\
\hline $\mathrm{N}$ & 4145 & 1424 & 990 & 340 & 0.0 & $0 \cdot 1$ & $2 \cdot 0$ & $1 \cdot 3$ & 0.2 & 0.2 & $5 \cdot 2$ & 0.9 \\
\hline 0 & 3559 & 963 & 850 & 230 & $1 \cdot 7$ & $1 \cdot 4$ & $1 \cdot 7$ & $1 \cdot 2$ & $0 \cdot 0$ & 0.0 & $4 \cdot 3$ & 1.5 \\
\hline P & 4480 & 1758 & 1070 & 420 & $2 \cdot 0$ & 0.4 & $1 \cdot 4$ & $1 \cdot 6$ & $0 \cdot 1$ & 0.1 & $5 \cdot 3$ & $2 \cdot 4$ \\
\hline Q & 3852 & 670 & 920 & 160 & $1 \cdot 2$ & $0 \cdot 2$ & $3 \cdot 3$ & 1.5 & $0 \cdot 1$ & 0.1 & 0.3 & 0.5 \\
\hline $\mathrm{R}$ & 6238 & 3014 & 1490 & 720 & $2 \cdot 3$ & $2 \cdot 0$ & $2 \cdot 2$ & $3 \cdot 0$ & $1 \cdot 3$ & 0.5 & $5 \cdot 6$ & 0.7 \\
\hline S & 8750 & 754 & 2090 & 180 & $2 \cdot 9$ & $1 \cdot 6$ & $4 \cdot 2$ & 0.8 & 0.8 & 0.5 & $5 \cdot 2$ & $2 \cdot 3$ \\
\hline All programmes & 4756 & 1863 & 1136 & 445 & $1 \cdot 7$ & $1 \cdot 3$ & $2 \cdot 6$ & $2 \cdot 3$ & $0 \cdot 4$ & 0.6 & $4 \cdot 1$ & $2 \cdot 4$ \\
\hline \multirow{2}{*}{$\begin{array}{l}\text { Recommended } \\
\text { servings/dt }\end{array}$} & \multirow{2}{*}{\multicolumn{2}{|c|}{$\begin{array}{l}\text { Males } \\
\text { Females }\end{array}$}} & & & 3 & & 8 & & 2 & & 8 & \\
\hline & & & & & 2 & & 6 & & 2 & & 7 & \\
\hline
\end{tabular}

${ }^{*}$ Recommendations for men and women, 31-50 years old ${ }^{(43)}$.

tThere were no milk product servings in any of the meals.

Table 3 Mean and median nutrient contents of the 70 meals sampled in eighteen programmes and the average requirements of 31-50year-old males and females

\begin{tabular}{|c|c|c|c|c|c|c|}
\hline \multirow[b]{2}{*}{ Variable } & \multirow[b]{2}{*}{ Mean } & \multirow[b]{2}{*}{ SD } & \multirow[b]{2}{*}{ Median } & \multirow[b]{2}{*}{ Min.-Max. ${ }^{*}$} & \multicolumn{2}{|c|}{ EAR } \\
\hline & & & & & Males & Females \\
\hline Protein (g) & $48 \cdot 0$ & $25 \cdot 0$ & $43 \cdot 0$ & $10-122$ & $46 \cdot 0$ & $38 \cdot 0$ \\
\hline Vitamin $A, \operatorname{RAE}(\mu \mathrm{g})$ & $411 \cdot 0$ & $283 \cdot 0$ & $394 \cdot 0$ & $17-1221$ & $625 \cdot 0$ & $500 \cdot 0$ \\
\hline Vitamin C (mg) & $99 \cdot 0$ & $77 \cdot 0$ & $77 \cdot 0$ & $1-298$ & $110 \cdot 0+$ & $95 \cdot 0 t$ \\
\hline Folate, DFE $(\mu \mathrm{g})$ & $226 \cdot 0$ & $125 \cdot 0$ & $199 \cdot 0$ & $40-720$ & $320 \cdot 0$ & $320 \cdot 0$ \\
\hline Vitamin $B_{6}(\mathrm{mg})$ & $1 \cdot 1$ & $0 \cdot 7$ & $1 \cdot 0$ & $0 \cdot 1-4 \cdot 5$ & $1 \cdot 1$ & $1 \cdot 1$ \\
\hline Thiamin (mg) & $1 \cdot 0$ & 0.5 & 0.9 & $0 \cdot 3-3 \cdot 0$ & $1 \cdot 0$ & 0.9 \\
\hline Niacin (mg) & $22 \cdot 0$ & $12 \cdot 0$ & $20 \cdot 0$ & $5-75$ & $12 \cdot 0$ & $11 \cdot 0$ \\
\hline Riboflavin (mg) & $1 \cdot 0$ & 0.6 & 0.9 & $0 \cdot 3-3 \cdot 1$ & $1 \cdot 1$ & 0.9 \\
\hline Vitamin $\mathrm{B}_{12}(\mathrm{mg})$ & $2 \cdot 7$ & $6 \cdot 5$ & $1 \cdot 6$ & $0 \cdot 1-53 \cdot 7$ & $2 \cdot 0$ & $2 \cdot 0$ \\
\hline Magnesium (mg) & $158 \cdot 0$ & $83 \cdot 0$ & $130 \cdot 0$ & $30-420$ & $350 \cdot 0$ & $265 \cdot 0$ \\
\hline Iron (mg) & $8 \cdot 1$ & $3 \cdot 4$ & $7 \cdot 5$ & $2 \cdot 8-17 \cdot 4$ & $6 \cdot 0$ & $8 \cdot 1$ \\
\hline Phosphorus (mg) & $667 \cdot 0$ & $330 \cdot 0$ & $595 \cdot 0$ & $130-1640$ & $580 \cdot 0$ & $580 \cdot 0$ \\
\hline Zinc (mg) & $6 \cdot 5$ & $4 \cdot 4$ & $5 \cdot 6$ & $1 \cdot 2-26 \cdot 0$ & $9 \cdot 4$ & $6 \cdot 8$ \\
\hline Total fibre $(\mathrm{g})$ & $10 \cdot 0$ & $6 \cdot 0$ & $9 \cdot 0$ & $1-31$ & $38 \cdot 0 \ddagger$ & $25 \cdot 0 \ddagger$ \\
\hline Calcium (mg) & $360 \cdot 0$ & $247 \cdot 0$ & $278 \cdot 0$ & $50-1258$ & $1000 \cdot 0 \ddagger$ & $1000 \cdot 0 \ddagger$ \\
\hline
\end{tabular}

RAE, retinol activity equivalents; DFE, dietary folate equivalents.

*Minimum and maximum values among all programmes.

tThe estimated average requirements (EAR) are presented for smokers because a high proportion of homeless individuals smoke ${ }^{(20)}$. The EAR for nonsmokers would be $35 \mathrm{mg} / \mathrm{d}$ less.

$\ddagger$ The Adequate Intakes were used in comparison with total fibre and calcium contents.

programmes failed to meet the EAR for magnesium. Half of the programmes had mean protein contents below the EAR for men and half had mean iron contents below the EAR of women. The average calcium and total fibre contents of meals in all programmes were well below the AIs for these nutrients (data not shown).

When portion sizes of all foods served in the meals were increased to achieve an average energy content equivalent to the EER for a small, sedentary woman, all or almost all programmes met the EARs for iron, phosphorus, protein, niacin, riboflavin, thiamin and vitamin $\mathrm{B}_{6}$. However, the average levels of folate, zinc, magnesium and vitamins $\mathrm{A}$, $\mathrm{B}_{12}$ and $\mathrm{C}$ in the meals in several programmes were still below median requirements. Additionally, the calcium and fibre content of meals in almost all programmes were below the AIs for these nutrients (data not shown). 
Table 4 Meal planning guide developed for meals to meet adults' nutrient requirements

\begin{tabular}{|c|c|c|}
\hline Food categories* & Serving sizet & Number of servings \\
\hline \multicolumn{3}{|l|}{ Grains group } \\
\hline Breads & 1 slice & 2 \\
\hline Pasta, rice, noodles & $\frac{1}{2}$ cup & \\
\hline Cereals & $30 \mathrm{~g}\left(\frac{1}{2}\right.$ cup $)$ & \\
\hline Bagel, pita, bun & $\frac{1}{2}$ of one & \\
\hline \multicolumn{3}{|l|}{ Meat and alternatives } \\
\hline Beef, poultry, pork, fish & $100 \mathrm{~g}$ & 2 \\
\hline Beans, lentils, chickpeas & 1 cup & \\
\hline \multicolumn{3}{|l|}{ Vitamin A-rich vegetables/fruit } \\
\hline Carrots & $\frac{1}{2}$ cup & 1 \\
\hline \multicolumn{3}{|l|}{ Mixed vegetables (frozen) } \\
\hline \multicolumn{3}{|l|}{ Peas (frozen) } \\
\hline \multicolumn{3}{|l|}{ Butternut squash } \\
\hline \multicolumn{3}{|l|}{ Vitamin B-rich (folate) vegetables/fruit } \\
\hline Beans, lentils, chickpeas & $\frac{1}{2}$ cup & 1 \\
\hline \multicolumn{3}{|l|}{$\begin{array}{l}\text { Dark greens, e.g. broccoli, } \\
\text { Spinach, Romaine lettuce }\end{array}$} \\
\hline \multicolumn{3}{|l|}{ Vitamin C-rich vegetables/fruit } \\
\hline Oranges/citrus fruits & 1 & 2 \\
\hline Orange juice (from concentrate) & $\frac{1}{2}$ cup & \\
\hline \multicolumn{3}{|l|}{ Grapefruit juice (from concentrate) } \\
\hline \multicolumn{3}{|l|}{ Sweet peppers } \\
\hline \multicolumn{3}{|l|}{ Apple juice with vitamin $C$ added } \\
\hline \multicolumn{3}{|l|}{ Broccoli } \\
\hline \multicolumn{3}{|l|}{ Other vegetables/fruit } \\
\hline Tomatoes (fresh, canned) & $\frac{1}{2}$ cup & 2 \\
\hline \multicolumn{3}{|c|}{ Potatoes, including dried potato products } \\
\hline \multicolumn{3}{|l|}{ Cauliflower } \\
\hline \multicolumn{3}{|l|}{ Corn (canned) } \\
\hline \multicolumn{3}{|l|}{ Vegetable juice } \\
\hline \multicolumn{3}{|l|}{ Melons } \\
\hline \multicolumn{3}{|l|}{ Apple juice } \\
\hline \multicolumn{3}{|l|}{ Milk products } \\
\hline Fluid milk & 1 cup & 2 \\
\hline Milk powder & $50 \mathrm{~g}\left(\frac{1}{2}\right.$ cup $)$ & \\
\hline Processed cheese slices & 2 slices & \\
\hline Yoghurt & $\frac{3}{4}$ cup & \\
\hline Solid cheeses & $50 \mathrm{~g}\left(3^{\prime \prime} \times 1^{\prime \prime} \times 1^{\prime \prime}\right)$ & \\
\hline
\end{tabular}

*The examples of foods in each food category were drawn from the list of foods found in the meals recorded. tBased on standard serving sizes found in Canada's Food Guide ${ }^{(43)}$.

A guide for planning more nutritionally adequate meals was developed, working with foods included in the meals recorded at these programmes (Table 4). On average, the meals constructed following this guide exceeded the EARs for all nutrients, except for magnesium, and approximated the AI for calcium (Table 5). The mean fibre content of the meals was still below the AI, but it was more than double the content of observed meals (Table 3). The mean energy content of the meals was only $838 \mathrm{~kJ}$ (200 kcal) higher than that of the observed meals (Table 2).

The mean per cent contribution of donated foods to the total energy content of meals ranged from $0 \%$ to $94 \%$; even within programmes using donations, there was wide variation in the per cent contribution of food donations from one meal to the next (Table 6). The percentage of energy from donations in a meal was positively associated with vitamin $\mathrm{C}$ content, and marginally significant positive relationships were observed for folate and thiamin (Table 7). The use of Box-Cox transformed nutrient variables in these analyses prohibits direct inferences about the magnitude of the effect, but some indication comes from the back-transformation of predicted values for vitamin $\mathrm{C}$. As the percentage of energy from food donations increased from $0 \%$ to $100 \%$ of the meal, vitamin $\mathrm{C}$ content increased from 40 to $100 \mathrm{mg} / \mathrm{meal}$. No associations were observed between the percentage of energy from donations and the total energy content, other nutrients or food group servings in meals (Table 7 ).

\section{Discussion}

Our results indicate that the meals served in most of the eighteen food programmes studied were insufficient to meet adults' daily energy and nutrient requirements. The low nutritional contribution of meals implies that homeless individuals cannot rely on these programmes to meet their needs, let alone replenish micronutrient stores depleted from frequent experiences of food deprivation 
Table 5 Energy and nutrient content of meals $(n 30)$ randomly generated following the meal planning guide

\begin{tabular}{|c|c|c|c|c|c|}
\hline Variable & Minimum & Maximum & Mean & SD & Requirement* $^{\star}$ \\
\hline Energy (kJ) & 3810 & 8336 & 5614 & 1097 & $\mathrm{n} / \mathrm{a}$ \\
\hline Energy (kcal) & $910 \cdot 0$ & $1991 \cdot 0$ & $1341 \cdot 0$ & $262 \cdot 0$ & $\mathrm{n} / \mathrm{a}$ \\
\hline Protein $(\mathrm{g})$ & $63 \cdot 0$ & $107 \cdot 0$ & $80 \cdot 0$ & $12 \cdot 0$ & $46 \cdot 0 t$ \\
\hline Vitamin A, RAE $(\mu \mathrm{g})$ & $443 \cdot 0$ & $1660 \cdot 0$ & $1065 \cdot 0$ & $241 \cdot 0$ & $625 \cdot 0$ \\
\hline Vitamin C (mg) & $86 \cdot 0$ & $234 \cdot 0$ & $142 \cdot 0$ & $35 \cdot 0$ & $110 \cdot 0$ \\
\hline Folate, DFE $(\mu \mathrm{g})$ & $219 \cdot 0$ & $852 \cdot 0$ & $484 \cdot 0$ & $176 \cdot 0$ & $320 \cdot 0$ \\
\hline Vitamin $B_{6}(\mathrm{mg})$ & $1 \cdot 1$ & $3 \cdot 1$ & 1.9 & 0.6 & $1 \cdot 1$ \\
\hline Thiamin (mg) & $0 \cdot 7$ & $2 \cdot 1$ & $1 \cdot 3$ & 0.3 & $1 \cdot 0$ \\
\hline Niacin $(\mathrm{mg})$ & $21 \cdot 0$ & $32 \cdot 0$ & $25 \cdot 0$ & $3 \cdot 0$ & $12 \cdot 0$ \\
\hline Riboflavin (mg) & $1 \cdot 4$ & $2 \cdot 9$ & $2 \cdot 0$ & 0.4 & $1 \cdot 1$ \\
\hline Vitamin $B_{12}(\mathrm{mg})$ & $0 \cdot 9$ & $5 \cdot 7$ & $3 \cdot 5$ & $1 \cdot 2$ & $2 \cdot 0$ \\
\hline Magnesium (mg) & $167 \cdot 0$ & $414 \cdot 0$ & $283 \cdot 0$ & $68 \cdot 0$ & $350 \cdot 0$ \\
\hline Iron (mg) & $6 \cdot 8$ & $20 \cdot 7$ & $13 \cdot 0$ & $4 \cdot 0$ & $8 \cdot 1 \ddagger$ \\
\hline Phosphorus (mg) & $951 \cdot 0$ & $1932 \cdot 0$ & $1399 \cdot 0$ & $242 \cdot 0$ & $580 \cdot 0$ \\
\hline Zinc (mg) & $7 \cdot 5$ & $14 \cdot 7$ & $11 \cdot 0$ & $1 \cdot 9$ & $9 \cdot 4$ \\
\hline Total fibre (g) & $10 \cdot 0$ & $36 \cdot 0$ & $22 \cdot 0$ & $8 \cdot 0$ & $38 \cdot 0 \S$ \\
\hline Calcium (mg) & $778 \cdot 0$ & $1468 \cdot 0$ & $1046 \cdot 0$ & $163 \cdot 0$ & $1000 \cdot 0 \S$ \\
\hline
\end{tabular}

RAE, retinol activity equivalents; DFE, dietary folate equivalents; $n / a$, not applicable.

${ }^{*}$ Requirement estimates are estimated average requirements (EAR) for males, 31-50 years old, unless otherwise noted.

tThe protein requirement is obtained from the reference adult male.

¥The EAR of iron for females, 31-50 years old, is shown because it is the highest requirement within this age group.

§Requirements for total fibre and calcium are presented as Adequate Intakes.

Table 6 Percentage of energy from donations in the average meals at the eighteen community food programmes

\begin{tabular}{lrrrrr}
\hline & & \multicolumn{3}{c}{ \% of energy from donations } \\
\cline { 3 - 6 } Programme & $n^{*}$ & Minimum & Maximum & Mean & SD \\
\hline A & 3 & 91 & 100 & 94 & 5 \\
B & 4 & 0 & 35 & 15 & 18 \\
C & 4 & 0 & 0 & 0 & \\
D & 4 & 90 & 100 & 97 & 5 \\
E & 4 & 34 & 84 & 64 & 22 \\
G & 3 & 16 & 73 & 44 & 28 \\
H & 4 & 0 & 0 & 0 & \\
I & 4 & 22 & 100 & 49 & 35 \\
J & 4 & 45 & 69 & 58 & 10 \\
K & 4 & 0 & 0 & 0 & \\
L & 4 & 68 & 100 & 88 & 15 \\
M & 4 & 0 & 22 & 10 & 12 \\
N & 4 & 0 & 61 & 37 & 26 \\
O & 4 & 0 & 66 & 32 & 34 \\
P & 4 & 0 & 0 & 0 & \\
Q & 4 & 0 & 30 & 8 & 15 \\
R & 4 & 0 & 12 & 4 & 6 \\
S & 4 & 45 & 96 & 81 & 24 \\
\hline
\end{tabular}

*Number of meals sampled per programme.

and dietary compromise ${ }^{(20)}$. While the generalisability of our results is clearly limited by the use of a small, non-random sample of programmes, our findings are consistent with programme users' reports of the low quality, limited selection and insufficient amount of foods served in meal programmes ${ }^{(11,17,20,44,52,53)}$. The results also help to explain how an analysis of the dietary intakes of homeless youth in Toronto could find little impact of programme use on youths' total energy and nutrient intakes ${ }^{(20)}$.

We have likely overestimated the true contribution of the meal programmes studied to individuals' total needs
Table 7 Linear relationship between the energy, nutrient and food group content of meals and the percentage of energy from donated foods*

\begin{tabular}{lclll}
\hline Variable & Slopet & sD & $F_{1 / 52}$ & $P$ value \\
\hline Energy (kcal) & 0.00003 & 0.0009 & 0.00 & 0.97 \\
Protein (g) & 0.01 & 0.007 & 0.03 & 0.87 \\
Vitamin A, RAE $(\mu \mathrm{g})$ & -0.01 & 0.02 & 0.21 & 0.65 \\
Vitamin C $(\mathrm{mg})$ & 0.06 & 0.02 & 9.23 & 0.0037 \\
Folate, DFE $(\mu \mathrm{g})$ & 0.0008 & 0.0004 & 3.75 & 0.058 \\
Vitamin $\mathrm{B}_{6}(\mathrm{mg})$ & 0.002 & 0.002 & 0.68 & 0.41 \\
Thiamin $(\mathrm{mg})$ & 0.003 & 0.002 & 3.42 & 0.070 \\
Niacin $(\mathrm{mg})$ & 0.001 & 0.002 & 0.23 & 0.64 \\
Riboflavin $(\mathrm{mg})$ & 0.0006 & 0.002 & 0.10 & 0.75 \\
Vitamin $\mathrm{B}_{12}(\mathrm{mg})$ & -0.004 & 0.005 & 0.58 & 0.45 \\
Magnesium (mg) & 0.0003 & 0.002 & 0.05 & 0.82 \\
Iron (mg) & 0.002 & 0.002 & 1.19 & 0.28 \\
Phosphorus (mg) & 0.01 & 0.02 & 0.31 & 0.58 \\
Zinc (mg) & -0.002 & 0.003 & 0.39 & 0.54 \\
Total fibre (g) & 0.004 & 0.005 & 0.91 & 0.35 \\
Calcium (mg) & 0.002 & 0.003 & 0.42 & 0.52 \\
Meat and alternative servings & $-0.002 \ddagger$ & $0.005 \ddagger$ & 0.12 & 0.7293 \\
Grain product servings & $0.002 \ddagger$ & $0.009 \ddagger$ & 0.04 & 0.8366 \\
Vegetable and fruit servings & $0.009 \ddagger$ & $0.007 \ddagger$ & 1.62 & 0.2083 \\
Milk product servings & $0.0006 \ddagger$ & $0.002 \ddagger$ & 0.09 & 0.7598 \\
\hline
\end{tabular}

RAE, retinol activity equivalents; DFE, dietary folate equivalents.

${ }^{*} n 54$ meals (excluding meals recorded in four programmes that did not use food donations).

tParameter estimate from mixed linear model, based on transformed intake variables.

‡Food group servings were not transformed, but rather the mixed linear model was conducted using a method of estimation that did not assume normality in the dependent variable.

because the meal records analysed represent 'best-case scenarios.' Portion sizes are often reduced and meals are altered during the course of meal service as supplies are depleted and other foods are substituted. Data on the dietary intakes of meal participants are needed to truly assess the meals' contributions to their total nutrient 
needs. In addition, data on height, weight, age, sex and usual physical activity levels of meal participants are required to obtain more accurate energy and nutrient requirement estimates.

The true nutrient needs of many homeless adults are likely higher than the requirement estimates applied here. Not only do the EAR represent medians of the requirement distribution for any one age-sex grouping, but these estimates are also designed to apply to healthy people. Given the high levels of poor health ${ }^{(4-14)}$ and nutrient inadequacies ${ }^{(20)}$ documented among samples of homeless groups in Canada, it is likely that some of their nutrient requirements exceed the estimates used. Furthermore, at any given time, some proportion of homeless women are pregnant ${ }^{(54)}$, elevating their nutrient requirements. If the true nutrient needs of individuals were known, meals would likely appear even more inadequate.

For simplicity in comparing meals to requirement estimates, we considered the meals' contribution only in relation to the days when they were provided. However, most programmes studied did not provide meals $7 \mathrm{~d} /$ week; thus, their true contribution must be less than what our analyses indicate because on some days, they contributed nothing. Conversely, we have underestimated the contributions of programmes that served more than one meal/d by considering only one meal. This underestimation was greatest in the three shelter programmes that served three meals and a snack daily. Whether examining all foods served would indicate that the programmes were meeting adults' daily nutrient requirements, however, is debatable. A recent study of shelter users in Toronto raised concerns about the quality of food provided $^{(53)}$; moreover, studies of shelter users elsewhere have revealed serious problems of dietary inadequacy $^{(30,34)}$. A more comprehensive examination of shelter meals is required to assess their nutrient adequacy.

Setting appropriate nutrient standards for charitable meal programmes hinges on understanding the role of these meals in relation to the total food intakes of those who use them. Studies of homeless individuals in Canada and elsewhere routinely document their difficulties obtaining enough to eat ${ }^{(17,37,44)}$. In the Canadian context, this struggle is revealed in the assortment of desperate strategies homeless individuals employ to acquire food, including panhandling, theft, retrieval of food discarded by others or receipt of free food from people who exploit them $^{(11,15,17,18,20,55,56)}$. The inadequacy and insecurity of such food acquisition strategies imply that substantial nutrient intakes are unlikely to be achieved on a daily basis from foods consumed outside charitable meal programmes. Homeless individuals may obtain food or beverages that provide additional energy during the course of a day, but they are unlikely to meet their micronutrient needs through other routes ${ }^{(20)}$. Thus we would argue that meal programmes providing one meal/ day or less to this extraordinarily vulnerable group should strive to supply meals that meet adults' daily requirements, particularly for protein and micronutrients. Our results indicate that these nutrient goals can be achieved through the provision of more nutrient-dense foods, such as milk products and micronutrient-rich vegetables and fruits, with minimal change in the energy content of the meals. However, changes in food selection are required. Simply increasing portion sizes will have little impact on the micronutrient levels of meals in most programmes because they include very little milk products, fruits and vegetables currently. Improving the nutritional quality of meals offered thus requires additional resources.

Most programmes in the present study relied, in part, on food donations collected through large, well-established, food redistribution networks. Contrary to expectations, given the extensive literature critiquing the quality of food donations distributed by food banks in Canada $^{(22-28)}$, meal quality was positively related to the use of donated foods in these programmes. This must to some extent reflect the limited funding available for food purchases in many programmes. Unfortunately, there is probably little scope for programmes to increase their supplies of donated foodstuffs. Despite the constant quest for more donations, food banks continue to report that demands for their services exceed supplies ${ }^{(21)}$. In distributing the donations they collect, food banks must weigh the needs of meal programmes for homeless adults against the needs of their extensive network of emergency food hamper programmes for domiciled families, as well as children's programmes, prenatal programmes and other valued community programmes that they supply. Thus, programmes for homeless individuals probably cannot make significant improvements in their meals without additional funds for food purchasing. Yet this also appears unlikely. Since 1999, the federal government has made some financial assistance available to communities to help them deal with local problems of homelessness, but funding has declined in recent years, and none of this funding is specifically dedicated to food programmes ${ }^{(57-60)}$.

While the present study has highlighted the low nutritional contribution of meals provided by community programmes, other problems have also been identified. Homeless individuals report difficulty obtaining meals because of the infrequent, short meal service hours in many programmes and the distances required to access different programmes at various times of the day or week $^{(11,17)}$. Moreover, programme users complain about having to stand in long line-ups for food, eat in what are often crowded, unpleasant settings and participate in prayer services or other activities as a prerequisite to obtaining food in some programmes ${ }^{(11,17,52)}$. Thus even if resources can be found to improve the nutritional adequacy of meals provided, the appropriateness of such fragmented, ad boc food provisioning as a long-term response to meeting the food needs of homeless people should be challenged. 


\section{Conclusion}

The ad hoc, voluntary nature of charitable food provisioning efforts in Canada speaks of the high levels of concern in communities for the plight of homeless individuals. However, our examination of the nutritional contribution of meals served in a sample of programmes in Toronto suggests that these initiatives may have limited potential to meet the food and nutrition needs of this group. While any meal is obviously 'better than nothing', a reliance on programmes providing meals of low nutritional quality will further compromise the nutritional health of homeless individuals. More resources are required to remedy this situation, highlighting the need for more systemic, policy responses to the needs of homeless individuals in Canada.

\section{Acknowledgements}

Conflicts of interest: The authors have no conflicts of interest.

Funding source: This study was funded in part by operating grants from the Canadian Institutes of Health Research (HPI - 66921) and Wellesley Institute (formerly the Wellesley Central Health Corporation).

Author contributions: V.T. conceived this study, C.T. conducted all the analyses presented in this manuscript, and both authors actively participated in the preparation of the manuscript.

Acknowledgements: The authors are indebted to Naomi Dachner, Amy MacDonald, Carol Greenwood and Dan Sellen for their helpful comments on this research.

\section{References}

1. Social Planning and Research Council of BC (2005) On our streets and in our Shelters... Results of the 2005 Greater Vancouver Homeless Count. http://www.gvrd.bc.ca/ homelessness/pdfs/HomelessCount2005Final.pdf (accessed May 2008).

2. McGuire M, MacCoy D, Scott S, McGuire M \& Lauzon C (2005) City of Greater Sudbury: Evaluation of Homelessness Initiatives. Toronto, ON: Cathexis Consulting Inc.

3. City of Toronto (2006) Street Needs Assessment: Results and Key Findings. http://www.toronto.ca/housing/pdf/ streetneedsassessment.pdf (accessed May 2008).

4. Frankish CJ, Hwang SW \& Quantz D (2005) Homelessness and health in Canada. Can J Public Health 96, S23-S29.

5. Hwang SW (2001) Homelessness and health. Can Med Assoc J 164, 229-233.

6. Lee TC, Hanlon JG, Ben-David J et al. (2005) Risk factors for cardiovascular disease in homeless adults. Circulation 111, 2629-2635.

7. Votta E \& Manion I (2004) Suicide, high-risk behaviors, and coping style in homeless adolescent males' adjustment. $J$ Adolesc Health 34, 237-243.

8. Hwang S (2003) Mental illness and mortality among homeless people. Acta Psychiatr Scand 103, 81-82.

9. Smart RG \& Walsh GW (1993) Predictors of depression in street youth. Adolescence 28, 41-53.

10. Adlaf EM \& Zdanowicz YM (1999) A cluster-analytic study of substance problems and mental health among street youths. Am J Drug Alcohol Abuse 25, 639-660.
11. Gaetz S, Tarasuk V, Dachner N \& Kirkpatrick S (2006) 'Managing' homeless youth in Toronto. Can Rev Soc Policy 58, 43-61.

12. Cheung AM \& Hwang SW (2004) Risk of death among homeless women: a cohort study and review of the literature. Can Med Assoc J 170, 1243-1247.

13. Hwang SW (2000) Mortality among men using homeless shelters in Toronto, Ontario. JAMA 283, 2152-2157.

14. Roy E, Haley N, Leclerc P, Sochanski B, Boudreau J-F \& Boivin J-F (2004) Mortality in a cohort of street youth in Montreal. JAMA 292, 569-574.

15. Bunston $\mathrm{T} \&$ B Breton M (1990) The eating patterns and problems of homeless women. Women Health 16, 43-62.

16. Breton M \& Bunston $T$ (1995) Physical and sexual violence in the lives of homeless women. Can J Commun Ment Health 11, 29-44.

17. Dachner N \& Tarasuk V (2002) Homeless 'squeegee kids': food insecurity and daily survival. Soc Sci Med $\mathbf{5 4}$, 1039-1049.

18. McCarthy B \& Hagan J (1992) Surviving on the street. The experiences of homeless youth. J Adolesc Res 7, 412-430.

19. Tarasuk V \& Woolcott L (1994) Food acquisition practices of homeless adults: insights from a health promotion project. J Can Diet Assoc 55, 15-19.

20. Tarasuk V, Dachner N \& Li J (2005) Homeless youth in Toronto are nutritionally vulnerable. J Nutr 135, 1926-1933.

21. Canadian Association of Food Banks (2006) HungerCount 2006. Toronto, ON: Canadian Association of Food Banks.

22. Tarasuk V \& Eakin JM (2003) Charitable food assistance as symbolic gesture: an ethnographic study of food banks in Ontario. Soc Sci Med 56, 1505-1515.

23. Tarasuk V \& Eakin JM (2005) Food assistance through 'surplus' food: insights from an ethnographic study of food bank work. Agric Hum Values 22, 177-186.

24. Teron AC \& Tarasuk VS (1999) Charitable food assistance: what are food bank users receiving? Can J Public Health 90, 382-384.

25. Jacobs Starkey L (1994) An evaluation of emergency food bags. J Can Diet Assoc 55, 175-178.

26. Kennedy A, Sheeshka J \& Smedmor L (1992) Enhancing food security: a demonstration support program for emergency food centre providers. J Can Diet Assoc 53, 284-287.

27. Rock M (2006) 'We don't want to manage poverty': community groups politicize food insecurity and charitable food donations. IUHPE - Promot Educ 13, 36-41.

28. Jacobs Starkey L \& Kuhnlein HV (2000) Montreal food bank users' intakes compared with recommendations of Canada's Food Guide to Healthy Eating. Can J Diet Prac Res 61, 73-75.

29. Langnase K \& Mullis JM (2001) Nutrition and health in an adult urban homeless population in Germany. Public Health Nutr 4, 805-811.

30. Darmon N, Coupel J, Deheeger M \& Briend A (2001) Dietary inadequacies observed in homeless men visiting an emergency night shelter in Paris. Public Health Nutr $\mathbf{4 2}$, $155-161$.

31. Evans NS \& Dowler EA (1999) Food, health and eating among single homeless and marginalized people in London. J Hum Nutr Diet 12, 179-199.

32. Booth S (2006) Eating rough: food sources and acquisition practices of homeless young people in Adelaide, South Australia. Public Health Nutr 9, 212-218.

33. Wicks R, Trevena LJ \& Quine S (2006) Experiences of food insecurity among urban soup kitchen consumers: insights for improving nutrition and well-being. J Am Diet Assoc 106, 921-924. 
34. Wolgemuth JC, Myers-Williams C, Johnson P \& Henseler C (1992) Wasting malnutrition and inadequate nutrient intakes identified in a multiethnic homeless population. J Am Diet Assoc 92, 835-839.

35. Johnson LJ \& McCool AC (2003) Dietary intake and nutritional status of older adult homeless women: a pilot study. J Nutr Elder 23, 1-21.

36. Laven GT \& Brown KC (1985) Nutritional status of men attending a soup kitchen: a pilot study. Am J Public Health 75, 875-878.

37. Cohen BE, Chapman N \& Burt MR (1992) Food sources and intake of homeless persons. J Nutr Educ 24, 45S-51S.

38. Rauschenbach BS, Frongillo EA, Thompson FE, Andersen EJY \& Spicer DA (1990) Dependency on soup kitchens in urban areas of New York state. Am J Public Health 80, $57-60$.

39. Bowering J, Clancy KL \& Poppendieck J (1991) Characteristics of a random sample of emergency food program users in New York: II. Soup kitchens. Am J Public Health 81, 914-917.

40. Carillo TE, Gilbride JA \& Chan MA (1990) Soup kitchen meals: an observation and nutrient analysis. J Am Diet Assoc 90, 989-991.

41. US Department of Agriculture, Agricultural Research Service (2005) USDA National Nutrient Database for Standard Reference Release 18. Nutrient Data Laboratory Homepage; http://www.nal.usda.gov/fnic/foodcomp (accessed February 2007).

42. SAS Institute Inc. (2004) SAS OnlineDoc ${ }^{(R)}$ 9.1.3. Cary, NC: SAS Institute Inc.

43. Health Canada (2007) Eating Well with Canada's Food Guide. H164-38/1-2007E. Ottawa, ON: Health Canada.

44. Antoniades M \& Tarasuk V (1998) A survey of food problems experienced by Toronto street youth. Can J Public Health 89, 371-375.

45. Institute of Medicine (1997) Dietary Reference Intakes for Calcium, Phosphorus, Magnesium, Vitamin D, and Fluoride. Washington, DC: National Academy Press.

46. Institute of Medicine (1998) Dietary Reference Intakes for Thiamin, Riboflavin, Niacin, Vitamin $B_{6}$, Folate, Vitamin $B_{12}$, Pantothenic Acid, Biotin, and Choline. Washington, DC: National Academy Press.

47. Institute of Medicine (2000) Dietary Reference Intakes for Vitamin C, Vitamin E, Selenium, and Carotenoids. Washington, DC: National Academy Press.
48. Institute of Medicine (2002) Dietary Reference Intakes: Vitamin A, Vitamin K, Arsenic, Boron, Chromium, Copper, Iodine, Iron, Manganese, Molybdenum, Nickel, Silicon, Vanadium, and Zinc. Washington, DC: National Academy Press.

49. Institute of Medicine (2003) Dietary Reference Intakes: Applications in Dietary Planning. Washington, DC: National Academies Press.

50. Institute of Medicine (2005) Dietary Reference Intakes for Energy, Carbohydrate, Fiber, Fat, Fatty Acids, Cholesterol, Protein, and Amino Acids. Washington, DC: National Academy Press.

51. Gurka MJ, Edwards LJ, Muller KE \& Kupper LL (2006) Extending the Box-Cox transformation to the linear mixed model. $J R$ Stat Soc Series A: Stat Society 169, 273-288.

52. Knowles C (2000) Burger King, Dunkin Donuts and community mental health care. Health Place 6, 213-224.

53. Hwang SW \& Bugeja AL (2000) Barriers to appropriate diabetes management among homeless people in Toronto. Can Med Assoc J 163, 161-173.

54. Dematteo D, Major C, Block B et al. (1999) Toronto street youth and HIV/AIDS: prevalence, demographics, and risks. I Adolesc Health 25, 358-366.

55. Gaetz S \& O'Grady B (2002) Making money: exploring the economy of young homeless workers. Work Employ Soc 16, 433-456.

56. Hagan J \& McCarthy B (1997) Mean Streets: Youth Crime and Homelessness. Cambridge, UK: Cambridge University Press.

57. The National Homeless Initiative (1999) National Homelessness Initiative. A Guide to the Supporting Communities Partnership Initiative (SCPI). Hull, Quebec: National Secretariat on Homelessness.

58. National Homelessness Initiative (2003) The Role of the Supporting Communities Partnership Initiative in Community Planning and Capacity Building. http://www21. hrdc-drhc.gc.ca/partners/communityreport/index_print_e.asp (accessed August 2003)

59. National Homelessness Initiative (2003) About the initiative. http://www21.hrdc-drhc.gc.ca/initiative/index_ e.asp (accessed August 2003).

60. Human Resources and Social Development Canada (2007) Homelessness Partnering Strategy. http://www.homelessness. gc.ca/home/index_e.asp (accessed May 2008). 